John James iudubon wes the first man in North Anerica to band birds, when in 1803 he pleced silver wire around the logs of a brood of phcebes. Twu of these birds roturned to the same place the following yoar.

Shorty aft.r tie turn of this contury, orrithologists decided that some nethod of marking birds would priduce valuable data which could be cbtained in no other way. Accordingly, in 1909, the Anerican Bird Banding Association wis formed. In 1920, the U.S. Biclogical Survey (now the Fish \& Vildife Service), realizing the tremendous possibilities of banding, took over this work. Canadian banders use U.S. bands, but in addition to the forms they make cut for the use of the U.S. Fish \& Wildilfe Service, they must nake out duplicate rec rds for the National Parks Buresu of the Cunadian government, and send in requests for permits, bands, etc. through ottawa.

To band bircs in Canada, one must obtain a permit from the National Parks Bureau, which is also signed by the Game Commissioner for his particular province. Recommendations from two recognized onithologists ere also necessery, and it is required that the person be at least eighteen vears of age. Bands and forms are then issued free of charge, but all equipment must be made or purchased by the bander himself.

All bands bear a number, and the inscription: "Notify Fish \& Wildlife Service, Finhington, D.C." (Older bands referred to the Biological Survey). On smaller bands, the legend is abbreviated and the address "washington, D.C." is placed on the inside of the band. The bands are made of aluninum, and come in ten sizes. If the correct size is properly placed on the bird's leg, there is no danger to the bird, and due to its extrene Iishtness, it doesn't cause the vird any concern.

Fell over tiree milition of these bunds have veen pleded on North American birds since 1920. Some 1700 people now devcte their spare time to this work without remuneration. Many interesting facts abut the migration, longevity, and habits of many species have boen bought to light through banding. Ore of the most recent and most notable of these, was the discovery of the wintering place, hitherto unknown to scientists, of the Chimey S.ift, when binds from 13 of these birds were recovered from Pcru last spring.

Bird-binding records nre of scientific value, and accordingly a thorough knowledge of all the birds in one's district is necessary. No conscientiuus bander ever places a band on a bird's leg unless he is positive as to its identity. Records, accurately listing the band number, species of bird banded, date and place of banding, and the sex and age of the bird when known, must be kept.

At first, the majority of the birds were banded as juveniles still in the nest. Later, simple Drop Traps were developed. Tith this.type, bait is placed under a screen box, with one end held u by a stick. When a bird enters beneath the trap, a watcher, some distance away, pulls a string which is attached to the stick.

futomatic traps, of rany types, have rroved their worth. The best and simplest are those omploying funnels or a simple tripping arrangement. Once the bird passes through the funnel into the trap, it is usually unable to find its way out. In other traps, the bird trips the door shut when it steps on a perch or wire within the trap.

No story of biri-banding would be complete without some mention of the late Jack Miner. He was a picneer in the true sense of the word, and did a great deal to popularize banding and conservation with the general public. Concentrating exclusively on ducks and geese, he made his own bands, with his name on one side and a verse of scripture on the other.

Every dead bird seen should be exarined carefully. It may carry a band. Such a band may have been placed on the bird it few weeks before by one of our Saskatchewan banders, or it might have been put on ten years vefore in Louisiana. Flatten the wand out and mail it to the Fish \& Wilcilife Service, Washington, D.C. If the bird is living, carefully record the full banc number, and release the bird with a band on it. In either case report when and where you found the bird, and any other information you may know about its cause of deuth, etc. A reply from Washington 
will be received, telling the finder when the birc was banded and by whon, as weII as its species, age and sex. They also notify the bander that his bird has been found and by whom.

At the present tine, pernits are not being issued to new banciers due to the shortage of labor and naterial for bands. However, if any of our members feel they would enjoy this interesting hobby, we would advise then to write now and tell the National Parks Bureau that they are interested, so they nay start at the first opportunity. Anyone hearing of the finding of a banded bird should rake sure that it is reported to Washington. It may prove to be an unusual or inportant record.

\section{DUCK DISASTER}

Four years ago a "rain" of ducks wes reported fron Foan Lake one foggy night early in November, when Bufflehesds dropped out of the sky over an area of several miles. A similar occurence took place this Fall a few miles north-eust of clair and an account of the happening was sent us by A. Sloan, who obtained the details from Don Knox, a furmer in the district.

It seems that the week beginning Nov. I2 was very foggy and the whole countryside was heavily covered with hoar-frost. On Nov. 15, Mr. Knox decided to burn a straw pile and started the fire about 7.30 in the evening. The next morning when driving along the highway he noticed a few dead ducks, but thought nothing of this as they could easily have collided with the telephone wires in the fog of the night before. However, a little way further on he noticed a family of Indians picking up sonething in his fields and he immedictely investigated.

To his amazement, he found hundreds of dead and dying ducks scattered all over his field and that of a neishbor. Some had smashed bodies, others broken legs and wings, while some biras, although uninjured, seened stunned and completely dazed. The Indians carried away a wagon box full of dead birds and cane back for wore. other nearby residents rescued some of the Iiving birds and took then home, releasing them in $a$ few days. Mr. SIoan saic he saw a sackful of the dead birds and they all appeared to be Lesser Scaups.

As for the cause of the disaster - The most plausible explanation seens to be that the ducks were confused with the fog to start with, and then the Iight from the bonfire illuminated the hoar-frost on the stubble, so that the ducks mistook it for water. They then tried to land at the same rate of speed with which they cone in on water. The result on frozen round was disastrous.

Queried as to how many ducks night have been involved, lir. Knox estinates that there were between five and six thousand at the very least.. A smull percentage of the birds were uninjured; these were unable to take off out of the stubble but, when picked up and thrown into the air, nade a successful get-away. of course only a. few were saved in this manner, and $\mathrm{Mr}$. Knox fears that nany fell prey to weasels and other predators as a few days later he found many bodies from which the heads had been eaten off.

In both disasters - at Clair this year and at Foam Lake in 1940 - fog seems to have been one of the major factors, although the Foatn Lake occurence presented several extremely puzzling points. If anyone has ever come across a sinilar duck trajedy it would be nost interesting to hear the details.

The very heavy southward flight of clucks this year has already been noted in the newspapers. H.M. Rsyner, Ituna, reported well over 10,000 Lesser Scaups on the lakes between Lebret and Fort Qu'Appelie on Nov. 2. Stuart Houston noted large numbers of 